\title{
KASVATUS\&AIKA
}

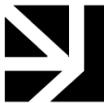

FRTAISARVIOITU

KOLLEGIALT GRANSKAD

PEER-REVIEWED

www.tsv.fi/tunnus

ArtikKeli

https://doi.org/10.33350/ka.69060

\section{Arkaluontoiset ja marginaaliset aiheet Suomen historian opetuksessa}

\author{
Eemeli Hakoköngäs, Inari Sakki, Anna-Maija Pirttilä-Backman, Katrin Kello \\ \& Hanna-Mari Salapuro
}

Tässä artikkelissa tarkastelemme historian opettajien käsityksiä Suomen historian arkaluontoisista ja marginaalisista aiheista, sekä sitä, miten opettajat ratkovat näihin aiheisiin liittyviä kysymyksiä työssään. Empiirinen aineisto on kerätty haastatteluin ja kyselyllä vuosina 2015-2016. Opettajien vastausten analysoinnissa ja tulkinnassa hyödynnetään taustateoriana sosiaalisten representaatioiden teoriaa (Moscovici 2008; Sakki, Menard \& Pirttilä-Backman 2017). Tutkimuksessa arkaluontoisella viitataan historian sisältöihin, joiden käsittelyn opettajat kokevat vaativan erityistä varovaisuutta tai hienotunteisuutta. Marginaalisella tarkoitetaan aiheita, joiden opettajat kokevat jäävän historian opetuksessa sivuun tai joiden he katsovat täydentävän opetussuunnitelmassa tai oppimateriaaleissa tarjottuja historian opetuksen sisältöjä.

Tutkimus osoittaa, että opettajat kokevat naisten ja vähemmistöjen roolin sekä mikrohistorian useimmin marginaaliin jääviksi aiheiksi. Sotiin ja vähemmistöjen rooliin liittyvät aiheet koetaan useimmin arkaluontoisiksi. Monikulttuurinen luokkaympäristö ja erilaisten oppilaiden kohtaaminen olivat tyypillisiä arkaluontoisuutta aiheuttavia tekijöitä. Tutkimuksen perusteella opettajat osoittivat selvää kiinnostusta pohtivaan, kyseenalaistavaan ja tulkitsevaan historian opetukseen. Marginaalisuuteen ja arkaluontoisuuteen liittyvien haasteiden ratkaiseminen koettiin opetusta rikastavaksi tekijäksi.

\section{Johdanto}

Opettajien käsitykset historiasta ovat osa historiapolitiikkaa koskevaa keskustelua, joka kouluympäristössä liittyy siihen, mitä tulisi opettaa ja miksi. Yhteistä menneisyyttä koskeva tieto on sosiaalisen identiteetin ja ryhmään kuulumisen kokemuksen kannalta tärkeää. Se luo kokemuksen yhteisön jatkuvuudesta ja auttaa ryhmää orientoitumaan tulevaisuuden 
haasteisiin (Ahonen 2017; Liu \& Hilton 2005). Opettajilla on tämän arkitiedon muodostumisessa ollut perinteisesti välittäjän tehtävä, joka on vähitellen muuttunut sisältöjen tarjoamisesta historiallisen ja moraalisen ajattelun edistäjäksi (Seixas \& Morton 2013; Van Drie \& Van Boxtel 2008). Vaikka ajattelun taitojen opettaminen on historianopetuksen tavoitteissa saanut painoarvoa, on kansallisvaltiolla edelleen historiakertomuksissa keskeinen rooli (Rantala \& Ahonen 2015). Samalla maahanmuutto ja kulttuurinen monimuotoistuminen muokkaavat opetuksen tavoitteita. Oppilasaineksen moninaistuminen sekä historianopetuksen perinteisen ja uuden tehtävän täyttäminen asettavat opettamiselle haasteen (Barton \& Levstik 2004; van Nieuwenhuyse \& Pires Valentim 2018). Esimerkiksi Rantala ja Ahonen (2015, 57-59) katsovat, että vallitsevassa tilanteessa suomalaisen identiteetin historiallinen rakentuneisuus ja sen hybridiluonne pitäisi kouluopetuksessa pystyä tuomaan nykyistä paremmin esiin (ks. myös Virta 2017).

\section{Historianopetus ja sosiaalinen tieto}

Historiatietoisuudessa on sosiaalipsykologisesti kiinnostavaa muun muassa se, miten historian kautta muodostetaan jaotteluja "meihin" ja "muihin" ja miten historiaan liittyviä vaikeita asioita käsitellään (Bilewicz ym. 2017). Liun ja Hiltonin (2005) mukaan historiaa koskevien käsitysten tutkiminen auttaa ymmärtämään niitä rooleja, joita historia meille tarjoaa, sekä sitä, miten historiaan liittyvä arkitieto ohjaa havaintojamme ja vaikuttaa esimerkiksi poliittisessa päätöksenteossa. Suomessa koulun tarjoama historianarratiivi on aikaisempina vuosikymmeninä keskittynyt tukemaan esimerkiksi myyttejä suomalaisten yhteisestä alkukodista ja suomalaisista selviytyjäkansana (Ahonen 2017). Vaikka jokin narratiivi on usein hallitsevampi kuin toiset, elää yhteiskunnissa erilaisia kertomuksia samoista historiallisista tapahtumista (esim. Bar-Tal ym. 2014).

Sosiaalisten representaatioiden eli ihmisten arkiteorioiden näkökulmasta voidaan puhua hegemonisista, emansipoituneista ja poleemisista representaatioista. Hegemoninen representaatio on ryhmän enemmistön jakama, kun taas emansipoituneilla representaatioilla viitataan yhteisön alaryhmien jakamiin käsityksiin. Poleemisista representaatioista puhutaan tilanteessa, jossa ryhmien representaatiot ovat ristiriidassa keskenään. (Moscovici 1988.) Tämän tutkimuksen kannalta kiinnostavia ovat myös niin sanotut metarepresentaatiot eli ryhmien käsitykset ulkoa tulevista odotuksista siitä, mitä tietystä aiheesta tulisi ajatella. Metarepresentaatiot voivat ohjata toimintaa jopa voimakkaammin kuin varsinaiset käsitykset. (Elcheroth, Doise \& Reicher 2011.)

Yhden kansallisen historian kertomus on akateemisessa historian tutkimuksessa ja sen myötä myös kouluopetuksessa kyseenalaistettu toisen maailmansodan jälkeen. Rantalan ja Ahosen (2015) mukaan osaselitys kehitykselle on vaiennettujen ryhmien historiakertomusten tulo julkisuuteen jälkikoloniaalisen kehityksen myötä. Toisaalta on korostettu edelleen tarvetta kolonialismiin ja vähemmistöihin liittyvän tiedon tuomisesta opetukseen entistä selkeämmin ja eksklusiivisen nationalismin avaamisesta inklusiiviseksi (Hakala ym. 2018; Wilkinson 2014; Grever 2007). Esimerkiksi Suomessa historianopetuksen tavoitteisiin on vuodesta 1994 alkaen sisältynyt eurooppalaisen historiakäsityksen rakentaminen, ja saman vuoden opetussuunnitelman yleisissä perusteissa määriteltiin suomalaisen kulttuurin perustuvan niin suomalaiseen, ruotsalaiseen kuin saamelaiseen ja romanienkin perintöön (Rantala \& Ahonen 2015). 2010-luvulla opetussuunnitelmissa on korostettu jälkimoderniin historiakäsitykseen liittyvää identiteettien moninaisuutta: identiteettiä pyritään edistämään niin yksilön, kansallisen, eurooppalaisen kuin globaalinkin identiteetin tasoilla (Opetushallitus 2015, 170). 
Seixas (2000) on erottanut historianopetuksen trendeistä perinteisen (kollektiiviseen muistamiseen suuntautuneen), jälkinationalistisen (tiedonalalähtöisen) sekä jälkimodernin (menneisyyskertomusten suhteellisuuteen keskittyvän) suuntautumistavan (ks. myös Carretero 2011). Suomessa esimerkiksi vuoden 2015 opetussuunnitelmassa painotetaan historian tekstitaitoja eli historian lähteiden tulkitsemista kontekstissaan. (Opetushallitus 2015; ks. myös Veijola 2016; Psaltis ym. 2017.) Vaikka historianopetuksen suunnittelussa on siirrytty sisällöllisestä taidolliseen opetukseen, ei opetus käytännössä ole aina seurannut ihanteita. Yksi syy tälle on, että oppimateriaalit ovat edelleen usein keskittyneet tiedonalaperusteiseen historian välittämiseen. Sisältöpainotteinen perinne näkyy historianopetuksessa yhä 2010-luvulla (Rantala \& Ahonen 2015, 118-120; Rantala 2012). Kansainvälisestikin tarkastellen näyttää siltä, että historianopetuksessa kilpailevat edelleen yhtenäisen kansallisen narratiivin, moninäkökulmaisuuden, dokumenttiperusteisen ja tulkinnallisuutta korostavan opetuksen suuntaukset (van Nieuwenhuyse \& Pires Valentim 2018; Psaltis ym. 2017).

Historioitsijat ilman rajoja -järjestö ehdottaa, että historianopetuksessa tulisi rakentaa dialogia eri historiakertomusten välille ja soveltaa tutkivia opiskelutapoja moninäkökulmaisuuden edistämiseksi (Hakala ym. 2018). Esimerkiksi McCully (2012) tarkasteli moninäkökulmaisen lähestymistavan mahdollisuuksia Pohjois-Irlannissa, jossa lähihistoriaan sijoittuva protestanttien ja katolisten välisen konflikti oli opettajalle haastava aihe. McCullyn havainto oli, että historian tekstitaitoja ja tutkivaa oppimista hyödyntävä lähestyminen auttaa nuoria saavuttamaan yhtä kansallista narratiivia monitasoisemman ymmärryksen menneisyydestä. Moniperspektiiviseen käsitykseen kuuluu myös historian tutkimuksen takana vaikuttavien ideologioiden ja motiivien arvioiminen ja siten refleksiivisen ajattelun opettaminen (van den Berg 2007; Ahonen 2017).

Myös opettajien omat käsitykset historiasta ja mahdollinen kuuluminen vähemmistöryhmään voivat vaikuttaa siihen, millaisia vaatimuksia opettaja kokee häneen kohdistuvan ja millaiseksi opetus muodostuu (Kello \& Wagner 2014). Carreteron (2011) mukaan historianopetuksessa esiintyy sekä "romanttista", isänmaanrakkauteen kannustavaa että "valistunutta", historian ymmärtämiseen tähtäävää ajattelua (ks. myös Sakki \& Pirttilä-Backman, 2019). Kellon ja Wagnerin (2017) tutkimuksessa virolaisten ja latvialaisten historianopettajien historiakäsityksistä suuri osa opettajista edusti "valistunutta" ajattelumallia. Myös Suomessa historian opettajaopiskelijoiden ajattelua 2000-luvun alkupuolella luonnehti "valistuneisuus": historiassa tärkeänä nähtiin kokonaiskuvan luominen, ilmiöiden yhdistäminen ja nykyisyyden ymmärtäminen (van den Berg 2007).

Suomessa on viime vuosikymmeninä akateemisessa tutkimuksessa purettu oppimateriaaleissa esiintyviä kansallisia myyttejä (esim. Ahonen 2017) ja tutkittu "vaiettuja aiheita" sekä nostettu aikaisemmin syrjään jääneitä näkökulmia, ryhmiä ja ilmiöitä keskusteluun ja vaadittu niiden tuomista kouluopetukseen (esim. Nygård 1998; Hakala ym. 2018). Kuitenkaan sitä, millaisia aiheita historianopettajat kokevat arkaluontoiseksi tai marginaaliseksi ja miten opettajat käsittelevät näitä aiheita, ei ole aikaisemmin tutkittu. Tämä tutkimus tarjoaa siis uutta tietoa arkaluontoista ja marginaalista historiaa koskevista käsityksistä. Arkaluontoisten ja marginaalisten aiheiden vertailukohtana tarkastellaan myös käsityksiä historian päälinjoista. Lisäksi tarkastelemme opettajien käsityksiä patriotismin ja nationalismin roolista historianopetuksessa. Jälkinationalistisessa historianopetuksessa näiden kahden aatteen suhde historianopetukseen on potentiaalisesti arkaluontoisuuden kokemusta herättävä (Kello 2014), vaikka käsitteitä itseään ei koettaisi arkaluontoisiksi. Esimerkiksi Rantala ja Veijola (2018) ovat havainneet, että vaikka nuorten historiatietoisuudessa on puutteita, osa heistä ammentaa historiaan liittyvää ylpeyttä suppeasta kansallisesta näkökulmasta, ennen muuta Suomen vaiheista toisessa maailmansodassa 


\section{Aineisto ja analyysi}

Tutkimuskysymyksiin vastaamiseksi hyödynsimme historianopettajilta kerättyä haastatteluja kyselyaineistoa. Aineistot ovat osa kansainvälisessä COST IS1205 Social Psychological dynamics of historical representations in the enlarged European Union -tutkimusverkostossa kerättyä Suomea koskevaa materiaalia. Haastattelut toteutettiin vuonna 2015 ja lomakekysely vuonna 2016.

Haastatellut historianopettajat $(\mathrm{N}=11)$, rekrytoitiin ottamalla yhteyttä koulujen rehtoreihin tai suoraan opettajiin. Haastattelut kestivät 30-90 minuuttia. Yhtä opettajaa lukuun ottamatta haastatellut työskentelivät pääkaupunkiseudulla. (Salapuro 2017.) Haastattelut toteutettiin puolistrukturoituna haastatteluna, jonka runko perustui Kellon (2014) käyttämiin teemoihin. Osallistujia pyydettiin kertomaan näkemyksiään kouluissa opetettavan Suomen historian pääpiirteistä sekä marginaalisiksi tai arkaluontoisiksi kokemistaan aiheista ja siitä, miten opettajat käsittelevät näitä aiheita opetuksessa. Lisäksi kysyttiin opettajien näkemystä nationalismin ja patriotismin roolista historianopetuksessa.

Sähköisellä lomakkeella toteutettu kysely sisälsi useita historianopetusta koskevia kysymyksiä, jotka oli muodostettu edellä mainitun COST-hankkeen Teaching sensitive issues työryhmän yhteistyönä (Savenije, Brauch \& Wagner 2019). Tässä artikkelissa keskitytään niihin lomakkeen kysymyksiin, jotka käsittelevät arkaluontoisuuteen ja marginaalisuuteen liittyviä aiheita, ja paneudutaan aiheisiin avokysymyksiin saatujen vastausten pohjalta. Linkki kyselylomakkeeseen lähetettiin koulujen nettisivuilta löytyvien historianopettajien sähköpostiosoitteisiin, ja vastaukset saatiin 93 opettajalta (aineiston keräämisestä ks. Sakki \& Pirttilä-Backman 2019). Vastauksia tulkitessa on huomioitava, että kyselyyn ovat vastanneet ne opettajat, joita aihe on kiinnostanut ja jotka kenties olivat jo pohtineet marginaali suuteen ja arkaluontoisuuteen liittyviä kysymyksiä työssään. Vastaajat työskentelivät kouluissa eri puolella Suomea. Lomakkeessa tiedusteltiin, oliko opettaja kokenut jonkin tai jotkin aiheet arkaluontoisiksi opetuksessa. Jos opettaja vastasi kyllä, häntä pyydettiin kertomaan missä mielessä, kenelle tai miksi kyseiset aiheet ovat arkaluontoisia. Marginaalisten historian aiheiden osalta kysyttiin, onko Suomen historiassa mitään tärkeää aihetta, joka on opetussuunnitelmasta unohdettu, jätetty liian vähälle huomiolle tai poliittisista syistä rajoitettu. Lisätietoja lomakkeesta ja kymmenen maan yhteishankkeen tuloksista on saatavilla Pedagogy, Culture \& Society -lehden vuoden 2019 ensimmäisestä numerosta.

Kummankin tutkimuksen osallistujat olivat työskennelleet historianopetuksen parissa useita vuosia: lomakkeeseen vastanneet 3-35 vuotta, haastatellut 10-35 vuotta. Suurimmalla osalla osallistujista oli kokemusta historian opettamisesta sekä peruskoulu- että lukiotasolla. Historian lisäksi osallistujat opettivat tyypillisesti yhteiskuntaoppia, mutta osalla oli myös kokemusta esimerkiksi uskonnon tai maantiedon opettamisesta. Kyselytutkimuksen ja haastattelujen toteuttamisessa sekä aineiston käytössä ja säilyttämisessä noudatettiin Tutkimuseettisen neuvottelukunnan ohjeita (2012).

Haastatteluaineisto analysoitiin laadullisen sisällönanalyysin periaatteiden mukaan. Ensin aineistoon tutustuttiin lukemalla se läpi kokonaisuudessaan useamman kerran. Tämän jälkeen aineistosta muodostettiin koodeja Atlas.ti-ohjelman avulla. Koodeja tarkennettiin ja karsittiin seuraavilla luku- ja luokittelukerroilla. Koodit saattoivat liittyä johonkin historian tapahtumaan (esim. sisällissota), aikakauteen (esim. kivikausi), pidempään kehityskulkuun (esim. jälleenrakennus) tai vaikkapa historian henkilöön (esim. Kekkonen). Seuraavaksi koodeja vertailtiin ja yhdisteltiin toisiinsa ja niistä muodostettiin ala- ja yläluokkia. Esimerkiksi romanien ja saamelaisten historiaa käsittelevät alaluokat yhdistettiin vähemmistöjen historia -yläluokaksi. Haastatteluaineiston luokittelussa pidettiin erillään 
Suomen historian tärkeimmät teemat, marginaaliset teemat ja arkaluontoiset teemat. Tämä erottelu juontui puolistrukturoidun haastattelurungon jäsentelystä eli yläteemat olivat esillä eri kysymyksissä. Vastaavasti kyselytutkimuksessa kysymykset marginaalisista ja arkaluontoisista aiheista esitettiin erikseen.

Vastausten luokittelu oli pääosin selkeää. Eniten pohdintaa aiheuttivat aluksi monitulkintaiset maininnat kuten viittaukset "poliittiseen historiaan". Haastattelujen kontekstista kävi kuitenkin ilmi, että esimerkiksi tällä viitattiin tyypillisesti poliittiseen päätöksentekoon ja päättäjiin, mutta teema oli hieman päällekkäinen esimerkiksi sotahistorian (jolla viitattiin enemmän sotatapahtumiin) tai jälleenrakennuksen (konkreettinen ja henkinen rakennustyö) kanssa.

Seuraavaksi esittelemme kummankin tutkimuksen tulokset. Ensiksi käsittelemme opettajien näkemyksiä Suomen historian päälinjoista. Ne muodostavat vertailukohdan marginaalissa oleville historian aiheille. Tämän jälkeen esittelemme marginaalisiksi ja arkaluontoisiksi koetut aiheet ja opettajien perustelut kyseisten aiheiden mainitsemiselle. Kolmanneksi tarkastelemme opettajien käsityksiä nationalismista ja patriotismista historianopetuksessa. Haastattelu ja kyselytutkimuksen tulokset on esitetty yhdessä toisiaan täydentäen.

\section{Suomen historia kehitystarinana}

Arkaluontoisten ja marginaalisten aiheiden ymmärtämiseksi on syytä tarkastella sitä, mitkä aiheet opettajien mukaan muodostavat keskeisen osan kansallista historiaa ja mitä kouluopetuksessa käsitellään. Asiaa kysyttiin haastatteluissa ja haastateltavia pyydettiin kuvailemaan omin sanoin kouluissa opetettavan Suomen historian päälinjat ja keskeiset aiheet. Taulukossa 1 on esitetty ne opettajien mainitsemat teemat, jotka esiintyivät aineistossa useammin kuin kerran. Suluissa oleva luku ilmaisee, montako kertaa aihetta käsiteltiin. Aiheet on esitetty karkeasti kronologisessa järjestyksessä.

\begin{tabular}{|l|}
\hline Kivikausi (2) \\
\hline Ruotsin vallan aika (5) \\
\hline Venäjän vallan/autonomian aika (13) \\
\hline Itsenäistyminen (5) \\
\hline Sotahistoria (7) \\
\hline Poliittinen historia (5) \\
\hline Jälleenrakennus (5) \\
\hline Kylmä sota ja kansainväliset suhteet (2) \\
\hline Rakennemuutos (2) \\
\hline Hyvinvointiyhteiskunta (2) \\
\hline Euroopan unioni (4) \\
\hline Globalisaatio (2) \\
\hline Yhteensä: 50 \\
\hline
\end{tabular}

Taulukko 1. Suomen historian keskeiset aiheet opettajien haastatteluissa $(N=11)$.

Useimmat haastatelluista nimesivät Venäjän vallan ajan (1808/09-1917) Suomen historian kertomuksen alkupisteeksi, eräänlaiseksi puoli-itsenäisyyden ajaksi. Osa ulotti historian alun, erityisesti eurooppalaisuuden juuret, Ruotsin vallan aikaan, ja kaksi haastatelluista katsoi Suomen historian juontuvan aina kivikaudesta asti. Haastattelujen perusteella Suo- 
men historian kulku muodostaa kronologisesti etenevän kehitystarinan, jossa korostuu maan kehitys moderniksi ja kansainväliseksi eurooppalaiseksi valtioksi. Opettajien kuvaus historian keskeisistä aiheista vastaa opetuksessa pitkään vallinnutta käsitystä suomalaisista "selviytyjäkansana" ja toisaalta uudempaa kertomusta eurooppalaisuudesta (Ahonen 2017).

Osa opettajista viittasi historian päälinjoista kertoessaan metarepresentaatioon siitä, että he kokivat heiltä odotettavan esimerkiksi kriittisempää lähestymistapaa kuin hegemonisen kansallisen kertomuksen kertomista. Esimerkiksi haastateltava 1 purki tämän käytännön ja odotusten välisen jännitteen huumoriin:

\section{Kyllä se tähän valtiolliseen historiaan niinku painottuu [...] niin sanottu suu- ri tarina [...] itsenäistyminen sodat ja selviytyminen ja sen jälkeen hyvinvoin- tivaltion rakentaminen [...] ehkä se tulee vähän niinku menestystarinana esi- tettyä (naurahtaa). (Haastateltava 1.)}

Haastattelujen perusteella pääpaino Suomen historiassa on ensimmäisen maailmansodan ja kylmän sodan välisessä ajassa. Tämä tulos selittyy osittain sillä, että itsenäisen Suomen historia on yksi lukion pakollisista historian kursseista. 1900-luvun ja itsenäisyyden historian painottuminen näkyy myös yleisissä historiakäsityksissä (Torsti 2012, 100-101), mikä kertoo ehkä osaltaan siitä, miksi kyseinen kurssi on valittu pakolliseksi. Suomen itsenäistyminen vuonna 1917 nähtiin tärkeänä käännekohtana, samoin 1900-luvun sodat (1918, 1939, 1941-1945). Sodat muodostivat yhtenäisen kokonaisuuden ("sotahistoria"), sillä ne liitettiin kertomukseen Suomen kansan jakautumisesta sisällissodassa ja uudelleen yhdistymisestä talvisodassa, kuten haastateltava 11 esittää kuvatessaan miten sodat jäsentävät itsenäi sen Suomen historian opetusta:

Verinen sisällissota jossa mietitään et minkä takia tämmönen käytiin [...] sen jälkeen oikeestaan kohti 20-30-lukuja millon yritettiin eheyttää kansakuntaa talvisotaan, jossa sitten ollaan ylpeitä ja ilosia siitä et oli onnistuttu kansakunta eheyttämään niin paljon että voitiin niinku yhtenä rintamana sotia Neuvostoliittoa vastaan. (Haastateltava 11.)

Edellisessä katkelmassa tulee esiin se kansalliseen kehityskertomukseen ja sosiaaliseen identiteettiin liittyvä piirre, että toisen maailmansodan kohdalla opetuksessa "ollaan ylpeitä ja ilosia" suomalaisten yhteisestä saavutuksesta.

Jälleenrakennus sodan jälkeen koettiin myös keskeiseksi osaksi kehitystarinaa. Rakennemuutos, hyvinvointivaltion rakentaminen ja globalisaatio luonnehtivat sotien jälkeisiä vuosikymmeniä. Euroopan unionin jäsenyys nähtiin historian viimeisimpänä käännekohtana - osa haastatelluista koki Euroopan unionin myös Suomen tarinan päätepisteenä. Torstin $(2012,244)$ havaintojen mukaan EU-jäsenyys näyttäytyy yleisemminkin kansallisen kertomuksen käännekohtana. Opettajien haastatteluista ei kuitenkaan ilmennyt yhteistä käsitystä EU-jäsenyyden merkityksestä.

\section{Marginaaliset aiheet Suomen historiassa}

Lomakekyselyssä 31 vastaajaa 93:sta vastasi kysymykseen Suomen historian opetuksen marginaalisista aiheista. Vastanneet opettajat mainitsivat kukin useita aiheita. Marginaalisella viitattiin kyselyssä aiheisiin, jotka eivät välttämättä tule lainkaan esiin opetussuunnitelmassa, tai seikkoihin, jotka on mainittu, mutta jotka jäävät vähäiseen rooliin suhteessa muihin, edellisessä luvussa mainitun kaltaisiin, historian keskeisinä pidettyihin aiheisiin verrattuna. 
Lomakevastauksissa useimmin esiin tuotu marginaaliseksi koettu aihepiiri oli Suomen "vaiettu sotahistoria", johon viitattiin 14 vastauksessa. Vaiettu sotahistoria liittyi sekä ensimmäiseen että toiseen maailmansotaan, kuten punaisten teloituksiin, suomalaisiin keskitysleireihin, sotavankien kohteluun, sotarikoksiin, Suomen ja natsi-Saksan yhteistyöhön, Lapin sotaan, naisten toimintaan sodassa ja partisaanihyökkäyksiin. Lisäksi vastauksissa mainittiin useammin kuin yhden kerran vähemmistöjen historia (8), suomalainen fasismi (4), naiset ja tasa-arvo (3), Ruotsin vallan aika (2) ja mikrohistoria (2).

Myös haastatteluissa painottuivat samat teemat. Taulukossa 2 on esitelty opettajien haastatteluissa mainitsemat marginaalisiksi koetut aiheet. Haastatellut opettajat mainitsivat kukin useamman aiheen. Suluissa oleva luku ilmaisee, kuinka usein aihetta käsiteltiin.

\begin{tabular}{|l|}
\hline Mikro-/psykohistoria (5) \\
\hline Naiset ja tasa-arvo (4) \\
\hline Suomen vaiettu sotahistoria (4) \\
\hline Vähemmistöjen historia (3) \\
\hline Kulttuuri-/arjen historia (3) \\
\hline Ajankohtaiset aiheet (esim. "Ukrainan kriisi') (2) \\
\hline Uudet, myyttejä purkavat historiatulkinnat (2) \\
\hline Marginaalisuus historianopetuksessa (2) \\
\hline Yhteensä: 25 \\
\hline
\end{tabular}

Taulukko 2. Suomen historian marginaaliset aiheet opettajien haastatteluissa $(N=11)$.

Opettajien vastausten perusteella voi tulkita, että marginaalisiksi koetaan etenkin ns. uuden historian tutkimuksen (esim. Burke 1991; Nygård 1998) esille tuomat näkökulmat arkeen sekä naisten ja erilaisten vähemmistöjen rooliin historiassa. Marginaaliset aiheet muodostavat siten ikään kuin vastakohdan edellisessä luvussa esitellylle Suomen historian pääkertomukselle. Marginaaliin koettiin jäävän myös historian pääkertomukseen (sodat) kuuluvien tapahtumien monipuolisempi tarkastelu, kuten Suomen "vaiettu sotahistoria".

Haastattelujen perusteella osa marginaaliseksi määritellyistä, vähemmistöihin ja vaiettuun sotahistoriaan liittyvistä aiheista koettiin luonteeltaan myös arkaluontoisiksi ja tätä pidettiin yhtenä syynä siihen, että ne ovat jääneet kansallisen kertomuksen ulkopuolelle. Näissä tapauksissa marginaalisen aiheen katsottiin esimerkiksi kyseenalaistavan historian kansallisen tehtävän. Esimerkiksi haastateltava 7 kertoo opetuksen tasapainottelevan "suuren kertomuksen" ja "uuden historian" välillä:

Varsinkin viime vuosina niin on pyritty ottaan [...] toisenlaisia vaihtoehtosia näkemyksiä ja tarinoita mut [...] kyl mä nään et silti et aika vahvasti on se edelleen se semmonen tietynlainen nationalistinen eetos siinä tarinassa. (Haastateltava 7.)

Marginaalisina pidetyistä teemoista naisten, vähemmistöjen ja arjen historiaan liittyvät aiheet olisi mahdollista luokitella yleisemmällä tasolla kuuluviksi mikrohistorialliseen lähestymistapaan. Niiden voi katsoa vastaavan nykypäivän monikulttuurisuuden, tasa-arvon ja individualismin kouluissa synnyttämiin tarpeisiin. Esimerkiksi yksi haastateltava mainitsi, kuinka opetussuunnitelma edelleen tukee "suurmiesten" historiaa, ja naisilla on vain sivullisen rooli. Perinteisen historianarratiivin katsottiin myös korostavan poliittista ja 
sotahistoriaa, jolloin "feminiinisempiin" näkökulmiin kuuluvat kulttuuri- ja mikrohistoria jäävät sivuun.

Toisaalta osa opettajista oli havainnut, että ruohonjuuritason yksilön näkökulmaa kuvaavista dokumenteista ja tarinoista on tullut oppikirjoissa entistä yleisempiä viime vuosina. Mikrohistoriallisen näkökulman etuna nähtiin sen kyky tuoda menneisyyden tapahtumat lähemmäs nykynuorta ja siten edesauttaa empatian tunteen kehittymisessä suhteessa menneisiin sukupolviin. Mikrohistorian yksilöllinen näkökulma on omiaan lisäämään empatiaa myös ulkoryhmän jäseniä kohtaan, koska toisin kuin makrohistoria, jossa toimijana ja toisinaan pahantekijän roolissa on koko kansakunta, mikrohistoria mahdollistaa eläytymisen erilaisiin rooleihin ilman kansakunnan jäsenyyden vahvaa painolastia (Bilewicz ym. 2017).

Naisten lisäksi vähemmistöjen historia mainittiin aiheena, jolla opettajat täydentävät tai haluaisivat täydentää kansallista kertomusta. Ryhmät, jotka haastatteluissa tuotiin esiin, olivat seksuaalivähemmistöt, kehitysvammaiset, saamelaiset, romanit, tataarit ja suomenruotsalaiset. Koska näiden ryhmien historia ei oppimateriaaleissa ole välttämättä osa kansallisen historian kertomusta, on nuorten saama tieto riippuvainen opettajan tietomäärästä ja kiinnostuksesta. Opettajien kokemuksen mukaan tasa-arvoa koskevat aiheet ovat tyypillisempiä yhteiskuntaopissa, mutta historianopetuksella olisi mahdollista syventää käsityksiä tasa-arvo- ja vähemmistökysymyksistä. Näiden kahden oppiaineen yhteistyön tiivistämistä on ehdotettu myös akateemisen historiantutkimuksen taholta (Hakala ym. 2018).

Opettajat kertoivat ratkaisevansa marginaalisuuteen liittyviä kysymyksiä täydentämällä opetusta omatoimisesti esimerkiksi tasa-arvoon liittyvillä teemoilla tai antamalla lukusuosituksia näitä aiheita koskeviin uusiin tutkimuksiin. Opettajat katsoivat, että nuoret historioitsijat eivät enää kanna aikaisempien sukupolvien taakkaa ja ovat siksi kykeneviä kyseenalaistamaan kansallisia myyttejä ja "vaiettuja aiheita". Marginaalisuutta koskevissa haastatteluvastauksissa nousi esiin käsitys siitä, että historian oppiminen on ikään kuin osallistumista jatkuvaan keskusteluun, joka muodostuu kansallisen narratiivin ja marginaalisten narratiivien välisestä vuorovaikutuksesta. Vaikka osa marginaalisista aiheista osoittautui myös arkaluontoisiksi, pääosin opettajat pitivät syrjään jääneiden aiheiden esiintuomista innostavana ja pedagogisesti hyödyllisenä. Marginaalisten aiheiden käsittelyä ei siten perusteltu ainakaan suoraan opetussuunnitelman tavoitteissa mainitulla oppilaiden identiteetin rakentamisella tai historiallisen ajattelun taitojen kehittämisellä vaan opetuksen sisältöjen rikastuttamisella.

\section{Arkaluontoiset aiheet historianopetuksessa}

Lomakekyselyssä 74 vastaajaa (93:sta) nimesi arkaluontoisia aiheita. Heistä 19 vastasi, etteivät he voi tai halua määritellä arkaluontoisia aiheita tarkemmin. Osa kritisoi käsitettä "arkaluontoinen" ja osa perusteli käsitystään sillä, että "opettajan pitää olla valmis..." tai "oppilaiden pitää tietää...". Osa mainitsi aiheita, jotka voisivat olla arkaluontoisia, kuten talvisota tai jatkosota. Toiseen maailmansotaan liittyvät aiheet mainittiin lomakevastauksissa useimmin: sotaan liittyvät Suomen ja Neuvostoliiton suhteet (9 vastaajaa), suomalaiset keskitysleirit Karjalassa (7) sekä holokausti (6). Ajanjakso 1939-1945 sai eniten arkaluontoisuutta koskevia mainintoja.

Toiseksi arkaluontoiseksi historian teemaksi nimettiin lähihistoria ja erityisesti Venäjä (12 vastaajaa). Vastaajat toivat tämän esiin muun muassa viittaamalla Krimin kriisiin (2014) ja presidentti Putinin harjoittamaan ulkomaanpolitiikkaan. Kun otetaan huomioon myös kaukaisempaan historiaan kohdistuvat maininnat, muodostaa Venäjä/Neuvostoliitto arkaluontoisten aiheiden keskeisen sisällön Suomen historian opetuksessa. Myös Suomen 
lähihistorian tapahtumat, etenkin kansallisten vähemmistöjen asema (6 vastaajaa) ja maahanmuutto/maahanmuuttopolitiikka (6) nimettiin arkaluontoisiksi. Näihin aiheisiin liittyvät kansainväliset lähihistorian ilmiöt ja tapahtumat, kuten islamismi ja terrorismi (6) ja LähiIdän konfliktit (5), koettiin niin ikään vaikeiksi. Kaukaisemmista historian tapahtumista mainittiin Suomen sisällissota (7).

Lomakevastauksissa 72 vastaajaa tarkensi, miksi jotkin asiat koetaan arkaluontoisiksi. Monikulttuurinen luokkaympäristö oli vastauksissa useimmin mainittu peruste. Osa vastaajista oli huolissaan siitä, että tiettyjen aiheiden käsittely voi kasvattaa ryhmien välisiä ristiriitoja tai ruokkia ennakkoluuloja. Venäläistaustaiset oppilaat mainittiin arkaluontoisuuden kokemuksen perusteeksi 18 vastauksessa, ja osa opettajista arvioi, että näiden oppilaiden joukossa on vahvasti venäläiseen historiakäsitykseen identifioituvia, joiden voi olla vaikea hyväksyä suomalaista tapaa lähestyä Suomen ja Venäjän/Neuvostoliiton historiaa. Myös venäläisen median mainittiin vaikuttavan näiden oppilaiden näkemyksiin historiasta. Moni vastaaja mainitsi, että myös suomalaisten oppilaiden sukutaustaan ja perheeseen liittyvät seikat (esimerkiksi karjalaisjuuret, vahvat poliittiset mielipiteet) voivat vaatia joidenkin aiheiden varovaista käsittelyä.

Haastatteluissa opettajat mainitsivat yhdeksäntoista erilaista tapahtumaa tai teemaa, jotka koettiin arkaluontoisiksi. Toiseen maailmansotaan liittyvät tapahtumat nousivat jälleen keskeisiksi, mutta eniten mainintoja sai Suomen sisällissota. Taulukossa 3 on lueteltu opettajien mainitsemat aiheet. Suluissa oleva luku ilmoittaa mainintojen määrän. Taulukossa on lueteltu vain aiheet, jotka saivat enemmän kuin yhden maininnan. Yksittäisiä mainintoja saivat isoviha, nälkävuodet, säädyt, kolonialismi, jääkäriliike, Suur-Suomi -ideologia, kommunismi Suomessa ja suomettuminen.

\begin{tabular}{|l|}
\hline Haastattelut \\
\hline Sisällissota (12) \\
\hline Jatkosota ja yhteistyö natsien kanssa (8) \\
\hline Vankileirit Suomessa (7) \\
\hline Juutalaiset ja holokausti (7) \\
\hline Talvisota (3) \\
\hline Venäjä/Neuvostoliitto (3) \\
\hline Kieliristiriidat (suomi-ruotsi) (2) \\
\hline Yhteensä: 42 \\
\hline
\end{tabular}

Taulukko 3. Arkaluontoiset aiheet opettajien haastatteluissa $(N=11)$.

Toisin kuin lomakevastauksissa haastatteluissa mainittiin useimmin yksittäisenä arkaluontoisena aiheena sisällissota. Neljä seuraavaksi useimmin mainittua aihetta liittyvät kaikki toiseen maailmansotaan. Vuosien 1939-1945 voi katsoa muodostavan arkaluontoisen historian ytimen, josta keskitysleirit nousevat selkeimpänä "konkreettisena" aiheena esiin.

Suomen sotahistorian ja siihen liittyvien teemojen (antisemitismi, vankileirit) arkaluontoisuuden koettiin riippuvan luokkatilanteesta, esimerkiksi oppilaiden kulttuuritaustasta. Myös oppilaiden ikä mainittiin tekijäksi, joka voi tehdä tiettyjen asioiden käsittelystä vaikeaa. Opettajien mukaan yksi keino ratkaista oppilaiden defenssireaktio on esittää ristiriitaiset tapahtumat opetussuunnitelman tavoitteiden mukaan osana laajempaa historiallista kontekstia. Tämä keino on tuotu esiin myös COST-verkoston suosituksissa ryhmien välisten konfliktien opettamisesta (Psaltis ym. 2017). Osa haastateltavista toi esiin, että opetta- 
jan kokemus jonkin asian arkaluonteisuudesta saattoi olla seurausta rajallisesta ajasta tai heterogeenisesta oppilaisaineksesta: opettajalla ei esimerkiksi ole tarpeeksi resursseja käsitellä vaikeaa teemaa hyödyntämällä moniperspektiivisyyttä. Esimerkiksi paikallisten näkökulmien sovittaminen yleiseen historiaan koettiin haasteeksi (vrt. Bilewicz ym. 2017) kuten haastateltava 2 kuvaa:

\section{Joittenkin aihepiirien kohdalla pitää erityisen tarkkaan miettiä niitä eri näkö- kulmia. Kaikkein haasteellisin aihe opettaa on se kaheksantoista sota. Ei sen takia että siinä olis nyt vielä tällasta painolastia ... vaan se syntyprosessi että miten se oli niinku joka paikkakunnalla Suomessa erilainen se kertomus. (Haastateltava 2.)}

Haastateltavien joukossa oli opettajia, jotka katsoivat, ettei Suomen historiassa ole enää arkaluontoisia aiheita. He kertoivat tuntevansa itsensä varmoiksi opettamaan mistä aiheesta tahansa. Tämä kokemus liittyi historian poliittisuuteen ja muodostui vertailussa aiempien opettajasukupolvien kanssa. Opettajat kokivat, että 1960- ja 1970-luvulla opettajien oli valittava poliittinen näkökantansa, joka ohjasi mitä ja miten historiaa oli opetettava. Nykypäivän opettajankoulutusjärjestelmän katsottiin valmistavan opettajat käsittelemään arkaluonteisia ja vaikeita asioita monipuolisesti.

Samoin kuin marginaalisten aiheiden kohdalla, osa haastatelluista katsoi, että arkaluontoiset aiheet voivat olla pedagogisesti hyödyllisiä, sillä synnyttäessään voimakkaita tunteita ne auttavat oppilaita keskittymään ja osallistumaan tunneilla. Opettajat, jotka nimesivät arkaluontoisia aiheita, kertoivat sisällyttävänsä ne tavalla tai toisella opetukseensa. Esimerkiksi suomalaisen antisemitismin historian opettaminen koettiin tavaksi välittää rasismin vastaisia ja suvaitsevaisia arvoja opetuksessa. Haastattelujen perusteella arkaluontoiset aiheet liittyivät siis Schwartzin ja Bardin (2001) esiin tuomaan historianopetuksen tehtävään arvojen välittäjänä ja Rantalan ja Ahosen $(2015,75)$ kuvaamaan jälkipositivistisen ajan ajatukseen historian roolista moraalisen ajattelun kehittäjänä.

\section{Nationalismi ja patriotismi historianopetuksessa}

Haastatteluissa opettajilta kysyttiin, millaiseksi he näkevät patriotismin ja nationalismin roolin historianopetuksessa. Kukin vastaaja sai itse määritellä kyseiset käsitteet. Kyselytutkimuksessa osa vastaajista toi käsitteet esille omatoimisesti osana arkaluontoisia historian aiheita. Osa haastatelluista totesi nationalismin ja patriotismin näkyvän kaikkialla: heidän mukaansa kansallismielisyys on kirjoitettu osaksi opetussuunnitelmaa ja opettajat on sosiaalistettu toteuttamaan sen tavoitteita. Tämä havainto on kiinnostava, sillä peruskoulun historian opetusta koskevassa opetussuunnitelmassa kansallinen narratiivi ja kansallinen identiteetti ovat läsnä lähinnä implisiittisesti (Rantala 2018). Haastatteluissa esiintyi myös metarepresentaatio siitä, että opettajien ei odotettu tuovan nationalistisia näkökulmia esiin. Samantyyppisesti kuin Suomen historian "suurta kertomusta" kuvailtaessa, odotus nationalismia koskevasta kritiikistä peitettiin huumorilla, kuten haastateltava 4 teki:

Eihän siitä [nationalismista] pääse irti esimerkiksi jos sodista puhutaan ja toisesta maailmansodasta niin kyllähän se tietysti (naurahtelua). Talvisodan henki niin kyllähän mä niinku nostan sen esille. Koska se sellanen henki oli olemassa. (Haastateltava 4.)

Osa haastatelluista oli varovaisia käyttäessään käsitteitä nationalismi ja patriotismi. Tyypillisesti haastateltava vastasi kysymykseen "mikä on nationalismin tai patriotismin rooli his- 
torianopetuksessa" määrittelemällä ensin millaisesta nationalismista tai patriotismista hän puhuu. Vastauksen aloittaminen määritelmällä kertoo siitä, että kyseiset käsitteet ovat monimerkityksisiä ja osittain negatiivisesti latautuneita, mutta myös siitä, että opettajat lähestyvät aihetta ammattimaisesti akateemisesta näkökulmasta. Usea opettaja teki eron "terveen" nationalismin ja äärikansallismielisyyden välille kuten haastateltava 11:

Historian tutkimus on syntynyt palvelemaan nationalismia [...] sehän on sisällä siinä historiassa eihän sitä voi väittää, ettei se olis, mut sit jos nationalismilla tarkotetaan tämmöstä äärinationalismia niin siitä mä yritän sanoutua irti. (Haastateltava 11.)

Lomakevastauksissa tuotiin esille historian perinteisen isänmaallisen tehtävän muuttuminen vaikeaksi haastatteluajankohtana julkisuudessa olleiden ääriliikkeiden myötä: "Isänmaallisuuden vahvistaminen on vähän monitulkintainen, koska se Soldiers of Odin pitää itseään hirveän isänmaallisena ja on siten kaapannut käsitteen itselleen ja pilannut sen" (Vastaaja 29). Osa haastatelluista kommentoi kysymystä myös mainitsemalla kuinka vaikeita tai jopa ärsyttäviä tällaiset käsitteet ovat. Heidän mukaansa yksi keino väistää vaikeudet on pyrkiä välttämään patriotismin tai nationalismin käsittelyä opetuksessa.

Kun osa haastatelluista näki nationalismiin ja patriotismin ongelmallisina, osa puolestaan koki, että kyse on lopulta siitä, miten opettaja käyttää kyseisiä käsitteitä. Yksi esiin tuotu keino oli tehdä nationalismi ja patriotismi näkyviksi aloittamalla määrittely käsitteiden juurista ja tarkastelemalla ilmiöitä aatehistoriallisesta näkökulmasta. Haastatteluissa tuotiin esille, että nationalismi voi olla sekä inklusiivista että eksklusiivista ja että havainnollisten esimerkkien kautta tämä ero voidaan tehdä oppilaille näkyväksi. Inklusiivinen nationalismi tarkoittaa vastaajien mukaan ylpeyttä omasta maasta ilman ulossulkemista tai vertailua, kun taas eksklusiivinen nationalismi perustuu ihmisten jakamiseen "meihin" ja "muihin". Muutamien vastaajien pohdinnan voi myös tulkita huoleksi siitä, häviääkö "mei dän" historia kokonaan, kuten haastateltava 3 esittää:

\section{Jos nyt mietitään et tehtäis joku Euroopan historia ja jotenkin yritettäis tehdä se poliittisesti korrektisti [...] niin meidän osuus ois ihan älyttömän pieni [...] että oisko sekään sitten se ihan oikea tapa. Et kyl ehkä se kansallinen historia opetuksessa [on säilytettävä]. (Haastateltava 3.)}

Opettajien suhtautuminen nationalismiin ja patriotismiin historianopetuksessa sisälsi useita tasoja: opettajat katsoivat käsitteiden sisältyvän aatehistoriaan, toisaalta niiden katsottiin myös ohjaavan historianopetusta, jolloin niihin liittyvien asioiden käsittelyn katsottiin vaativan tarkkuutta tai ainakin erityistä valmistautumista. Haastatteluista ja kyselystä erottui myös joukko opettajia, jotka olivat huolissaan "terveen" kansallismielisyyden katoamisesta (vrt. Grever \& Stuurman 2007).

\section{Johtopäätökset: Arkaluontoisuus ja marginaalisuus opetuksen haasteina ja mahdollisuuksina}

Kouluopetuksen painotukset muuttuvat, mutta kansallisten myyttien ja historian kertomuksen päälinjojen muutokset vievät aikaa, kuten Ahonen (2017) on osoittanut. Haastateltujen opettajien luonnehdinnat Suomen kansallisen historian keskeisistä aiheista, autonomian ajasta sekä maailmansotien roolista noudattavat aikaisempien tutkimusten tuloksia (Ahonen 1998; Torsti 2012). Hegemonisen kertomuksen yksipuolisuus on tiedostettu ja van den Bergin (2007) vuonna 2005 haastattelemat opettajaopiskelijat kritisoivat vallitsevaa historian- 
opetusta siitä, ettei se tarjoa riittävää kokonaiskuvaa menneisyydestä. Myös Historioitsijat ilman rajoja on ehdottanut historian kokonaiskuvan laajentamista esimerkiksi kansainvälisyyden ja vähemmistöjen kertomukset huomioimalla (Hakala ym. 2018).

Tässä tutkimuksessa opettajat nimesivät mikrohistorian sekä naisten ja vähemmistöjen tarinat marginaalisiksi. Opettajat kuitenkin kertoivat pyrkivänsä korjaamaan puutetta täydentämällä aktiivisesti kansallisen historian kertomusta. Naisten marginaalinen rooli korostui vastauksissa, vaikka kuten Ahonen $(2017,99,112)$ toteaa, vahva nainen on yksi historiakirjoissa pitkään eläneen tasa-arvomyytin elementti. Oppikirjoissa naiset ovat kuitenkin edelleen pääosin nimettömiä toimijoita, ja kenties heidän marginaalisuutensa muodostuu vertailussa historian nimettyihin toimijoihin, joista useimmat ovat miehiä (vrt. Torsti 2012).

Marginaaliseksi koettujen aiheiden voi tulkita heijastavan nykypäivän tarpeita ja arvoja, kuten monikulttuurisuutta ja tasa-arvoa, ja toisaalta laajemmin ns. uuden historian käsittelemiä kysymyksiä (esim. Burke 1991; Nygård 1998). Vaikka kyselyssä vain kolmasosa vastaajista nimesi historian marginaalisia aiheita, valtaosa nimesi arkaluontoisia aiheita. Haastatteluissa kaikki haastatellut puolestaan nimesivät marginaaliin jääviä teemoja, mutta haastattelutilanteessa heillä oli laajempi mahdollisuus perustella ja pohtia mitä marginaalisuus on. Haastatteluissa välittyi käsitys siitä, että opettajat olettivat heiltä odotettavan julkisuu dessa esiintyvien aiheiden esiintuomista. Vastaavasti kansallisen historian perinteisten teemojen, kuten kansallismielisyyteen liittyvän talvisodan hengen, mainitsemiseen sisältyi odotus kuulijan kriittisyydestä (vrt. Elcheroth, Doise \& Reicher 2011). Tämänkaltaisten metarepresentaatioiden tutkiminen voi jatkossa tarjota kiinnostavan mahdollisuuden syventää ymmärrystä eri tahoilta tulevien odotusten vaikutuksesta opettajien käsityksiin siitä, mitä pitäisi opettaa.

Historian sisältöjen täydentäminen omatoimisesti osoittaa, etteivät opettajat vain välitä opetussuunnitelman ja oppimateriaalien tarjoamia sisältöjä, vaan pohtivat aktiivisesti historian eri puolia ja kyseenalaistavat hegemonisia kertomuksia. Havainto on linjassa sen kanssa, että 2010-luvun opetussuunnitelmat eivät ohjaa käsittelemään tiukasti kansallisen historian kaanonin sisältöjä, vaan tarjoavat suhteellisen vapaat kädet opetuksen suunnitteluun (Rantala 2018). Tällöin kuitenkin opetusmateriaalit voivat asettaa rajat sille, mitä tunneilla käsitellään (Hakala ym. 2018). Pitkälle meneviä päätelmiä opettajien ajattelumaailman mahdollisesta muutoksesta sisällöllisestä taitopainotteiseen opetukseen on aineiston perusteella vaikea tehdä, kun otetaan huomioon vastaajien suhteellisen pieni lukumäärä. Kahden erityyppisen aineiston (haastattelut ja kysely) yhdistäminen asettaa haasteen myös vastausten tulkitsemiselle. Tämän tutkimuksen haastatteluosion haastateltavat ja haastattelurunko olivat erilaiset kuin kyselytutkimuksessa tai esimerkiksi van den Bergin (2007) tekemissä opettajaopiskelijoiden haastatteluissa, ja on mahdollista, että tämän tutkimuksen toteutustapa on saattanut johdattaa opettajia tuomaan omaa aktiivisuuttaan enemmän esiin.

Sotiin, erityisesti toiseen maailmansotaan, liittyvä kokemus arkaluontoisuudesta vaikuttaa sekä haastattelujen että lomakevastausten perusteella olevan laajasti jaettu. Vähemmistöjen rooli historiassa oli toinen molemmissa aineistoissa hahmottunut laajasti jaettu arkaluontoiseksi koettu aihe. Nämä havainnot ovat yhteneviä Kellon (2016) Viron ja Latvian historianopettajien haastatteluista sekä Kellon ja Raudseppin (2017) lomakekyselystä tekemien tulkintojen kanssa.

Sotaan liittyvien aiheiden arkaluontoisuus eri maissa on ymmärrettävää, sillä sotaan tapahtumana liittyy useimmiten erilaisia tulkintoja sekä aina jako vähintään kahteen ryhmään (Bar-Tal ym. 2014). Käytännössä sotahistorian arkaluonteisuus liitettiin useimmiten venäläistaustaisten oppilaiden suhtautumiseen ja siihen, miten kyseiset historian tapahtumat on mahdollista esittää monikulttuurisessa luokassa loukkaamatta kenenkään tunteita. 
Näissä tapauksissa arkaluontoisuus muodostui oppilaiden kohtaamisesta eikä esimerkiksi siitä, että aihe olisi ollut poliittisesti arka. Vaikeimmat aiheet voivat heijastua myös oppimateriaalien suunnitteluun. Esimerkiksi Ahonen $(2017,94)$ toteaa, että tietyt sotaan liittyvät aiheet, kuten partisaanihyökkäykset, jäävät edelleen oppikirjoissa vaille mainintoja.

Ulossulkevaan tai integroivaan historiaan liittyvänä yleisempänä kysymyksenä voi pohtia sitä, millaisia mahdollisuuksia kansallinen narratiivi tarjoaa inklusiiviseen historiaan erityisesti monikulttuurisissa luokissa (Harris \& Reynolds 2014; Wilkinson 2014; Grever 2007). Kuinka Suomen historian kertomukseen kuuluvat vaiheet tehdään merkityksellisiksi monikulttuurisen luokan oppilaille, jos monikulttuurisuudella tai vähemmistöryhmillä ei ole näkyvämpää roolia historian kertomuksessa? Opetussuunnitelmat (esim. Opetushallitus 2015) tähtäävät oppilaiden yksilöllisen identiteetin vahvistamiseen, mutta vähemmistöihin kuuluvalle oppimateriaalit eivät edelleenkään tarjoa samaistumiskohtia (Hakala ym. 2018). Opettajien haastatteluissa oppilaiden identiteetin rakentaminen ei myöskään noussut esiin opetuksen tavoitteena. Tärkeämmäksi syyksi esimerkiksi marginaalisten aiheiden käsittelyyn mainittiin kiinnostuksen herättäminen historiaa kohtaan.

Opetuksen kannalta keskeisenä arkaluontoisuuteen liittyvänä haasteena opettajat toivat esiin paikallisuuden ja laajemman kontekstin yhteensovittamisen vaikeuden. Mahdollisuus omaksua erilaisia näkökulmia olisi kuitenkin keskeistä ryhmien välisen empatian ja ymmärryksen turvaamisen kannalta (Bilewicz ym. 2017, ks. myös Psaltis ym. 2017 sekä Hakala ym. 2018). Miten arkaluonteisia aiheita pitäisi sitten opettaa? Sosiaalipsykologinen tutkimus on osoittanut, että kokemus kollektiivisesta syyllisyydestä oman maan menneisyyteen liittyvissä asioissa toimii positiivisena virikkeenä ryhmien välisten suhteiden parantamisessa (Branscombe ym. 2007). Kouluopetuksen arki on kuitenkin sosiaalipsykologisia koeasetelmia monimutkaisempaa, ja onkin esitetty, että kollektiivinen syyllistäminen historianopetuksessa voi kääntyä hyvää tarkoitusperäänsä vastaan ja johtaa joitakuita esimerkiksi välttelemään kontaktia "ulkoryhmän" edustajien kanssa (Imhoff ym. 2012; Bilewicz ym. 2017).

Bilewicz ja kumppanit (2017) ovat tutkineet holokaustin opetusta Saksassa ja Puolassa ja siihen pohjaten tuovat esiin kolme näkökulmaa, jotka arkaluontoisten aiheiden opetuksessa olisi hyvä huomioida: 1) empatiaan perustuva opetus, jossa menneisyyden väärinteoista syyllistämisen sijaan keskitytään katumuksen tunteen herättämiseen, jolloin keskiössä eivät ole oman "sisäryhmän" toteuttamat julmuudet vaan "ulkoryhmän" kokema kärsimys, 2) esimerkkitarinat auttajasankareista, jotka oman henkensä kaupalla pyrkivät auttamaan oman "sisäryhmänsä" uhkaamia "ulkoryhmäläisiä" ja 3) paikallisen identiteetin korostaminen kansallisen sijaan, mikä mahdollistaa sisä- ja ulkoryhmän jäsenten mieltämisen osaksi samaa ryhmää ja helpottaa toisen kärsimysten ja näkökulmien huomioimista. Seixas (2000) on puolestaan korostanut yleisesti taitopainotteisen historianopetuksen merkitystä keinona välttää ryhmäjakoihin johtavan historiakäsityksen syntyminen. Bilewiczin ja kumppaneiden sekä Seixasin ajatusten tuominen käytäntöön ei kuitenkaan ole helppoa esimerkiksi siksi, että niin perusopetuksen kuin lukionkin opetuksen sisällöt painottuvat edelleen taitojen kustannuksella eivätkä tarjoa johdonmukaista suuntaa historianopetukselle (Rantala 2018).

Tässä tutkimuksessa haastatellut opettajat osoittivat selvää kiinnostusta pohtivaan, kyseenalaistavaan ja tulkitsevaan historianopetukseen. Carreteron (2011) jaottelua käyttäen, tutkittujen historian opettajien voi katsoa edustavan "valistunutta" historiakäsitystä ja argumentoivan sen kautta myös marginaalisten aiheiden opettamisen tärkeyttä. Kriittisen valistuneisuuden voi tulkita ohjaavan oppilaita moniarvoisuuteen ja erilaisten näkökulmien huomioimiseen. Marginaalisten aiheiden käsittely nähtiin tavaksi välittää opettajan tärkeinä 
pitämiä arvoja kuten rasisminvastaisuutta. Vaikka myös kansallisen identiteetin ainesten välittäminen koettiin tärkeäksi, ei sitä haluttu tehdä ahtaan nationalistisessa hengessä.

Opettajien vastaukset kertovat siitä, että he kokevat olevansa hyvin valmistautuneita kohtaamaan haastavia tilanteita: opettajat ovat tietoisia tiettyjen aiheiden mahdollisesta arkaluontoisuudesta ja halukkaita luomaan moninäkökulmaisempaa kuvaa kansallisesta historiasta. Vaikuttaa siltä, että esimerkiksi McCullyn (2012) esittämät tulokset moninäkökulmaisen historian eduista ovat osa kyselyyn vastanneiden historian opettajien historiakäsitystä. Keskeisenä esteenä moninäkökökulmaisen historian opettamiseen koettiin kuitenkin rajallinen aika. Tästä näkökulmasta viime vuosinakin aika ajoin käyty keskustelu histo rianopetuksen tuntimäärien ja pakollisten kurssien vähentämisestä johtaisi tilanteeseen, jossa moninäkökulmaisuuden saavuttaminen olisi entistä vaikeampaa.

Artikkelin kirjoittajat kiittävät kaikkia haastatteluihin osallistuneita ja kyselyyn vastanneita opettajia.

\section{Kirjallisuus}

Ahonen, Sirkka 1998. Historiaton sukupolvi. Historian vastaanotto ja historiallisen identiteetin rakentuminen 1990-luvun nuorison keskuudessa. Helsinki: Suomen historiallinen seura.

Ahonen, Sirkka 2017. Suomalaisuuden monet myytit. Kansallinen katse historian oppikirjoissa. Helsinki: Gaudeamus.

Bar-Tal, Daniel, Oren, Neta \& Nets-Zehngut, Rafi 2014. Sociopsychological analysis of conflict-supporting narratives: A general framework. Journal of Peace Research 51 (5), 662-675. https://doi.org/10.1177/0022343314533984

Barton, Keith C. \& Levstik, Linda S. 2004. Teaching history for the common good. Lontoo: Routledge.

Bilewicz, Michal, Witkowska, Marta, Stubig, Silviana, Beneda, Marta \& Imhoff, Roland 2017. How to Teach about the Holocaust? Psychological Obstacles in Historical Education in Poland and Germany. Teoksessa Psaltis, Charis, Carretero, Mario \& ČehajićClancy, Sabina (toim.), History Education and Conflict Transformation: Social Psychological Theories, History Teaching and Reconciliation. Basingstoke: Palgrave Macmillan, 169-197. https://doi.org/10.1007/978-3-319-54681-0 7

Burke, Peter 1991. Overture: the New History, its Past and its Future. Teoksessa Burke, Peter (toim.), New Perspectives on Historical Writing. Cambridge: Polity Press, 1-23.

Branscombe, Nyla, Schmitt, Michael \& Schiffhauer, Kristin 2007. Racial attitudes in response to thoughts of White privilege. European Journal of Social Psychology 37 (2), 203-215. https://doi.org/10.1002/ejsp.348

Carretero, Mario 2011. Constructing patriotism. Teaching of history and historical memory in globalized world. Charlotte: IAP.

Elcheroth, Guy, Doise, Willem \& Reicher, Stephen 2011. On the knowledge of politics and the politics of knowledge: How a social representations approach helps us rethink the subject of political psychology. Political Psychology 32 (5), 729-758. https://doi.org/ 10.1111/j.1467-9221.2011.00834.x

Grever, Maria 2007. Plurality, Narrative and the Historical Canon. Teoksessa Grever, Maria \& Stuurman, Siep (toim.), Beyond the Canon. History for the Twenty-first Century. Basingstoke: Palgrave Macmillan, 31-47. https://doi.org/10.1057/9780230599246_3 
Grever, Maria \& Stuurman, Siep (toim.) 2007. Beyond the Canon. History for the Twentyfirst Century. Basingstoke: Palgrave Macmillan. https://doi.org/ $\underline{10.1057 / 9780230599246}$

Hakala, Emma, Hakola, Iina \& Laakso, Jenni (toim.) 2018. Kenen historia? Raportti monipuolisen historiantutkimuksen, -opetuksen ja vuoropuhelun tilasta ja haasteista Suomessa. HWB Report 3, 10/2018. Helsinki: Historians without borders in Finland.

Harris, Richard \& Reynolds, Rosemary 2014. The history curriculum and its personal connection to students from minority ethnic backgrounds. Journal of Curriculum Studies 46 (4), 464-486. https://doi.org/10.1080/00220272.2014.881925

Imhoff, Roland, Bilewicz, Michał \& Erb, Hans-Peter 2012. Collective regret versus collective guilt: Different emotional reactions to historical atrocities. European Journal of Social Psychology 42 (6), 729-742. https://doi.org/10.1002/ejsp.1886

Kello, Katrin 2014. The functions and contexts of general education history teaching: social and professional representations in Estonia and Latvia. Tartto: Tarton yliopisto.

Kello, Katrin 2016. Sensitive and controversial issues in the classroom: Teaching history in a divided society. Teachers and Teaching 22 (1), 35-53. https://doi.org/ $\underline{10.1080 / 13540602.2015 .1023027}$

Kello, Katrin \& Raudsepp, Maaris 2017. Kas kui hästi tahta, võib iga teema tundlikuks muuta? Eesti õpetajate kogemused tundlike teemadega ajalootunnis. Eesti Haridusteaduste Ajakiri 5 (2), 106-132. https://doi.org/10.12697/eha.2017.5.2.05

Kello, Katrin \& Wagner, Wolfgang 2014. Intrinsic and Extrinsic Patriotism in School: Teaching History After Estonia's Critical Juncture. International Journal of Intercultural Relations 10, 48-59. https://doi.org/10.1016/j.ijintrel.2014.08.016

Kello, Katrin \& Wagner, Wolfgang 2017. History Teaching as 'Propaganda'? Teachers' Communication Styles in Post-Transition Societies. Teoksessa C. Psaltis, M. Carretero, \& S. Čehajić-Clancy (toim.), History Education and Conflict Transformation: Social Psychological Theories, History Teaching and Reconciliation. Basingstoke: Palgrave Macmillan, 201-229. https://doi.org/10.1007/978-3-319-54681-0 8

Liu, James H. \& Hilton, Denis J. 2005. How the past weighs on the present: Social representations of history and their role in identity politics. British Journal of Social Psychology 44 (4), 537-556. https://doi.org/10.1348/014466605X27162

Liu, James H. \& László, Janos 2007. A narrative theory of history and identity. Social identity, social representations, society, and the individual. Teoksessa Moloney, Gail \& Walker, Ian (toim.), Social representations and identity. Content, Process, and Power. New York: Palgrave Macmillan, 85-107. https://doi.org/10.1348/014466605X27162

McCully, Alan 2012. History teaching, conflict and the legacy of the past. Education, Citizenship and Social Justice 7 (2), 145-159. $\underline{\text { https://doi.org/ }}$ $\underline{10.1177 / 1746197912440854}$

Moscovici, Serge 1988. Notes towards a description of social representations. European Journal of Social Psychology 18 (3), 211-250. https://doi.org/10.1002/ejsp.2420180303

Moscovici, Serge 2008. Psychoanalysis: Its image and its public. Iso-Britannia: Polity.

Nygård, Toivo 1998. Erilaisten historiaa. Marginaaliryhmät Suomessa 1800-luvulla ja 1900-luvun alussa. Jyväskylä: Gummerus.

Opetushallitus 2014. Perusopetuksen opetussuunnitelman perusteet 2014. Helsinki: Opetushallitus.

Opetushallitus 2015. Lukion opetussuunnitelman perusteet 2015. Helsinki: Opetushallitus. 
Psaltis, Charis, Carretero, Mario \& Čehajić-Clancy, Sabina (toim.) 2017. History Education and Conflict Transformation: Social Psychological Theories, History Teaching and Reconciliation. Basingstoke: Palgrave Macmillan.

Psaltis, Charis, McCully, Alan, Agbaria, Ayman, Makriyianni, Chara, Pingel, Falk, Karahasan, Hakan, Carretero, Mario, Oguz, Mete, Choplarou, Rena, Philippou, Stavroula, Wagner, Wolfgang \& Papadakis, Yiannis 2017. Recommendations for the History Teaching of Intergroup Conflicts. COST IS 1205 Working Group. DOI: 10.13140/ RG.2.2.12927.61602

Rantala, Jukka 2012. Peruskoululaisten historian osaaminen arvioinnin kohteena. Historiallinen Aikakauskirja 110 (4), 443-450.

Rantala, Jukka 2018. Historiapolitiikkaa koulun opetussuunnitelman avulla. Politiikka 60 (2), 112-123.

Rantala, Jukka, \& Ahonen, Sirkka 2015. Ajan merkit. Historian käyttö ja opetus. Helsinki: Gaudeamus.

Rantala, Jukka \& Veijola, Anna 2016. Historiallisen tiedonmuodostuksen periaatteet hukassa. Historiallinen Aikakauskirja 114 (3), 267-277.

Sakki, Inari, Menard, Rusten \& Pirttilä-Backman, Anna-Maija 2017. Sosiaaliset representaatiot: yhteisön ja mielen välinen silta. Teoksessa Gronow, Antti \& Kaidesoja, Tuukka (toim.), Ihmismielen sosiaalisuus. Helsinki: Gaudeamus, 104-129 [www-lähde]. < https://tuhat.helsinki.fi/portal/fi/publications/sosiaaliset-represe(0fb0c4c1-bf35-4340$\underline{8 \mathrm{ec} 1-05 \mathrm{~b} 3 \mathrm{ba} 3 \mathrm{ba} 0 \mathrm{e} 7) \cdot \mathrm{html}}>$.

Sakki, Inari \& Pirttilä-Backman, Anna-Maija 2019. Aims in teaching history and their epistemic correlates: A study of history teachers in ten countries. Pedagogy, Culture \& Society 27 (1), 65-85. https://doi.org/10.1080/14681366.2019.1566166

Salapuro, Hanna-Mari 2017. National history teaching among Finnish history teachers Resources, challenges, controversies. Julkaisematon pro gradu -tutkielma. Helsingin yliopisto, Valtiotieteellinen tiedekunta, Sosiaalipsykologian oppiaine.

Savenije, Geerte, Brauch, Nicola \& Wagner, Wolfgang 2019. Sensitivities in history teaching across Europe and Israel. Pedagogy, Culture \& Society 27 (1), 1-6. https:// doi.org/10.1080/14681366.2019.1566163

Schwartz, Shalom H. \& Bardi, Anat 2001. Value hierarchies across cultures: Taking a similarities perspective. Journal of cross-cultural Psychology 32 (3), 268-290. https:// doi.org/10.1177/0022022101032003002

Seixas, Peter 2000. Schweigen! die Kinder! Or does postmodern history have a place in the schools? Teoksessa Stearns, Peter, Seixas, Peter \& Wineburg, Sam (toim.), Knowing, Teaching and Learning History. New York University Press, 19-37.

Seixas, Peter \& Morton, Tom 2013. Les six concepts de la pensée historique. Montréal: Modulo.

Stuurman, Siep, \& Grever, Maria 2007. Introduction: Old canons and new histories. Teoksessa Grever, Maria, \& Stuurman, Siep (toim.), Beyond the Canon. History for the Twenty-first Century. Basingstoke: Palgrave Macmillan, 1-16. https://doi.org/ $\underline{10.1057 / 9780230599246 \quad 1}$

Torsti, Pilvi 2012. Suomalaiset ja historia. Helsinki: Gaudeamus.

Tutkimuseettinen neuvottelukunta 2012. Hyvä tieteellinen käytäntö ja sen loukkausepäilyjen käsitteleminen Suomessa [www-lähde]. < http://www. tenk. fi/sites/tenk. fi/files/ HTK ohje verkkoversio040413. pdf. pdf\# overlaycontext $=$ fi $/$ ohjeet-ja-julkaisut $>$ (Luettu 16.1.2018.) 
van den Berg, Marko 2007. Yksi historia monimutkaistuvassa maailmassa: Historian olemus ja historian suuret kertomukset luokanopettajaopiskelijoiden historiatietoisuudessa. Historiallis-yhteiskuntatiedollisen kasvatuksen tutkimus- ja kehittämiskeskuksen tutkimuksia. Helsinki: Helsingin yliopisto.

van Drie, Jannet \& van Boxtel, Carla 2008. Historical reasoning: Towards a framework for analyzing students' reasoning about the past. Educational Psychology Review 20 (2), 87-110. https://doi.org/10.1007/s10648-007-9056-1

van Nieuwenhuyse, Karel \& Pires Valentim, Joaquim (toim.) 2018. The Colonial Past in History Textbooks - Historical and Social Psychological Perspectives. Charlotte: Information Age Publishers.

Veijola, Anna 2016. Historiatietoisuus, historiallinen ajattelu ja historian tekstitaidot: Uuden opetussuunnitelman moninaiset lähtökohdat. Kasvatus ja Aika 10 (2), 6-18 [www-lähde]. < https://journal.fi/kasvatusjaaika/article/view/68610/29936 >.

Virta, Arja 2017. Bridging History Education and the Diversity of Historical Cultures. Teoksessa Åström Elmersjö Henrik, Clark, Anna \& Vinterek, Monika (toim.), International Perspectives on Teaching Rival Histories. Pedagogical Responses to Contested Narratives and the History War. Lontoo: Palgrave Macmillan, 63-83. https://doi.org/ 10.1057/978-1-137-55432-1_4

Wilkinson, Matthew L. N. 2014. The concept of the absent curriculum: the case of the Muslim contribution and the English National Curriculum for history. Journal of Curriculum Studies 46 (4), 419-440. https://doi.org/10.1080/00220272.2013.869838

Wineburg, Sam 2001. Historical thinking and other unnatural acts: Charting the future of teaching the past. Philadelphia: Temple University Press.

VTT, FM Eemeli Hakoköngäs työskentelee Helsingin yliopiston valtiotieteellisessä tiedekunnassa projektisuunnittelijana.

VTT Inari Sakki on sosiaalipsykologian apulaisprofessori Itä-Suomen yliopistossa.

VTT Anna-Maija Pirttilä-Backman on sosiaalipsykologian professori Helsingin yliopistossa.

Ph.D. Katrin Kello työskentelee erityisasiantuntijana Viron tiedeneuvostossa (Estonian Research Council).

VTM Hanna-Mari Salapuro on valmistunut sosiaalipsykologiksi Helsingin yliopistosta. 